\title{
Acromegaly caused by atypical pituitary adenoma
}

\author{
Maria Manuel Costa ${ }^{1,5}$, Ana Saavedra ${ }^{1,5}$, Lígia Castro², Margarida Ayres Basto ${ }^{3}, J^{2}$ sué Pereira ${ }^{4}$, \\ Eduardo Vinha1 ${ }^{1}$, Davide Carvalho1,5
}

'Department of Endocrinology, Diabetes and Metabolism, Centro Hospitalar São João, Porto, Portugal; ${ }^{2}$ Pathology, Centro Hospitalar São João, Porto, Portugal; ${ }^{2}$ Neurorradiology, Centro Hospitalar São João, Porto, Portugal, 4Neurosurgery, Centro Hospitalar São João, Porto, Portugal; 4Faculty of Medicine, University of Porto, Porto, Portugal

\section{INTRODUCTION}

Diagnostic criteria for an atypical adenoma include invasive growth, elevated mitotic index, Ki-67 labeling index greater than $3 \%$ and extensive p53 immunoreactivity.

Atypical pituitary adenomas have higher risk of aggressive behavior in particular by the higher growth, local invasion and high risk of recurrence after surgery

In acromegaly the resistance to somatostatin analogues may be another manifestation of these adenomas since higher levels of Ki-67 are associated with poor response to therapy.

Radiotherapy is reserved for when surgery and medical therapy fails to control the disease. The experience of the use of temozolomide in aggressive adenomas is extremely limited.

\section{CASE REPORT}

\section{Identification}

\section{1 year-old, woman}

\section{Past medical history}

- Carpal tunnel syndrome

- Thyroid nodule

- Arthralgia

Therapy: trazodone $100 \mathrm{mg} /$ day

bromazepam $6 \mathrm{mg} /$ day

\section{History}

- Headaches with 8 years of evolution

- Growth of the hands

- Hyperhidrosis

- Enlargement of the lips with 3 years of evolution

- Episode of visual change that reversed spontaneously Endocrine team

\section{Physical examination \\ - $\mathrm{W}=66.5 \mathrm{Kg}, \mathrm{H}=1.57 \mathrm{~m}, \mathrm{BMl}=$ $27 \mathrm{Kg} / \mathrm{m} 2$ \\ - Visual field examination normal}

\section{Exam already carried out}

- Pituitary CT: Pituitary mass lesion hourglass-shaped. The lesion appears to invade the tank Meckel

\begin{tabular}{|c|c|c|c|c|}
\hline \multicolumn{2}{|c|}{ Parameter } & \multicolumn{2}{|c|}{ Result } & $\begin{array}{c}\text { Reference } \\
\text { range }\end{array}$ \\
\hline \multicolumn{2}{|c|}{$\mathrm{GH}$} & \multicolumn{2}{|c|}{$25.6 \mathrm{ng} / \mathrm{mL}$} & $<8$ \\
\hline \multicolumn{2}{|c|}{ IGF-1 } & \multicolumn{2}{|c|}{$1689 \mathrm{ng} / \mathrm{mL}$} & $64-336$ \\
\hline \multicolumn{2}{|c|}{ PTH } & \multicolumn{2}{|c|}{$50.2 \mathrm{pg} / \mathrm{mL}$} & $10.0-65.0$ \\
\hline \multicolumn{2}{|c|}{$\mathrm{T}_{4} \mathrm{~L}$} & \multicolumn{2}{|c|}{$0.95 \mathrm{ng} / \mathrm{dL}$} & $0.70-1.48$ \\
\hline \multicolumn{2}{|c|}{ TSH } & \multicolumn{2}{|c|}{$0.88 \mathrm{uUI} / \mathrm{mL}$} & $0.35-4.94$ \\
\hline \multicolumn{2}{|c|}{ Prolactin } & \multicolumn{2}{|c|}{$21.2 \mathrm{ng} / \mathrm{mL}$} & 4.8-23.3 \\
\hline \multicolumn{2}{|c|}{ Cortisol } & \multicolumn{2}{|c|}{$10.9 \mathrm{ug} / \mathrm{dL}$} & 6.2-19.4 \\
\hline \multirow{6}{*}{ 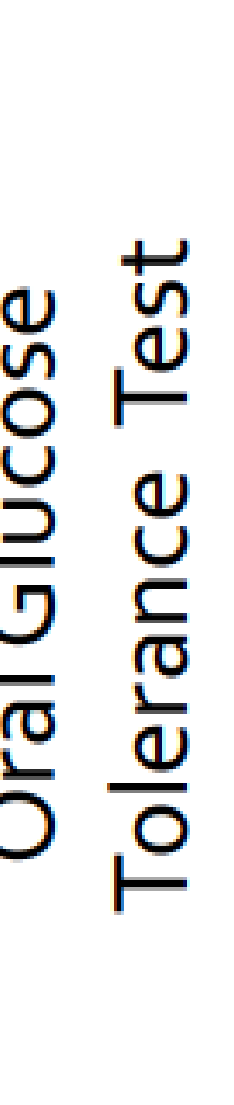 } & $\begin{array}{l}\text { Time } \\
\text { (min) }\end{array}$ & $\begin{array}{l}\text { Glucose } \\
\text { (mg/dL) }\end{array}$ & \begin{tabular}{|l} 
Insulin \\
$(\mathrm{uU} / \mathrm{mL})$
\end{tabular} & $\begin{array}{c}\mathrm{GH} \\
(\mathrm{ng} / \mathrm{mL})\end{array}$ \\
\hline & 0 & 106 & 32.6 & 24.1 \\
\hline & $30^{\prime}$ & 199 & 186.2 & 17.3 \\
\hline & $6 o^{\prime}$ & 197 & 199.8 & 15.8 \\
\hline & $90^{\prime}$ & 207 & 330.8 & 14.7 \\
\hline & $120^{\prime}$ & 204 & 4331.9 & 12.7 \\
\hline
\end{tabular}

\section{Pituitary MRI - december 2013}

Pituitary lesion with $24 \mathrm{~mm}$ craniocaudal diameter and 5 $\mathrm{mm}$ transverse diameter with invasion of the cavernous sinus.
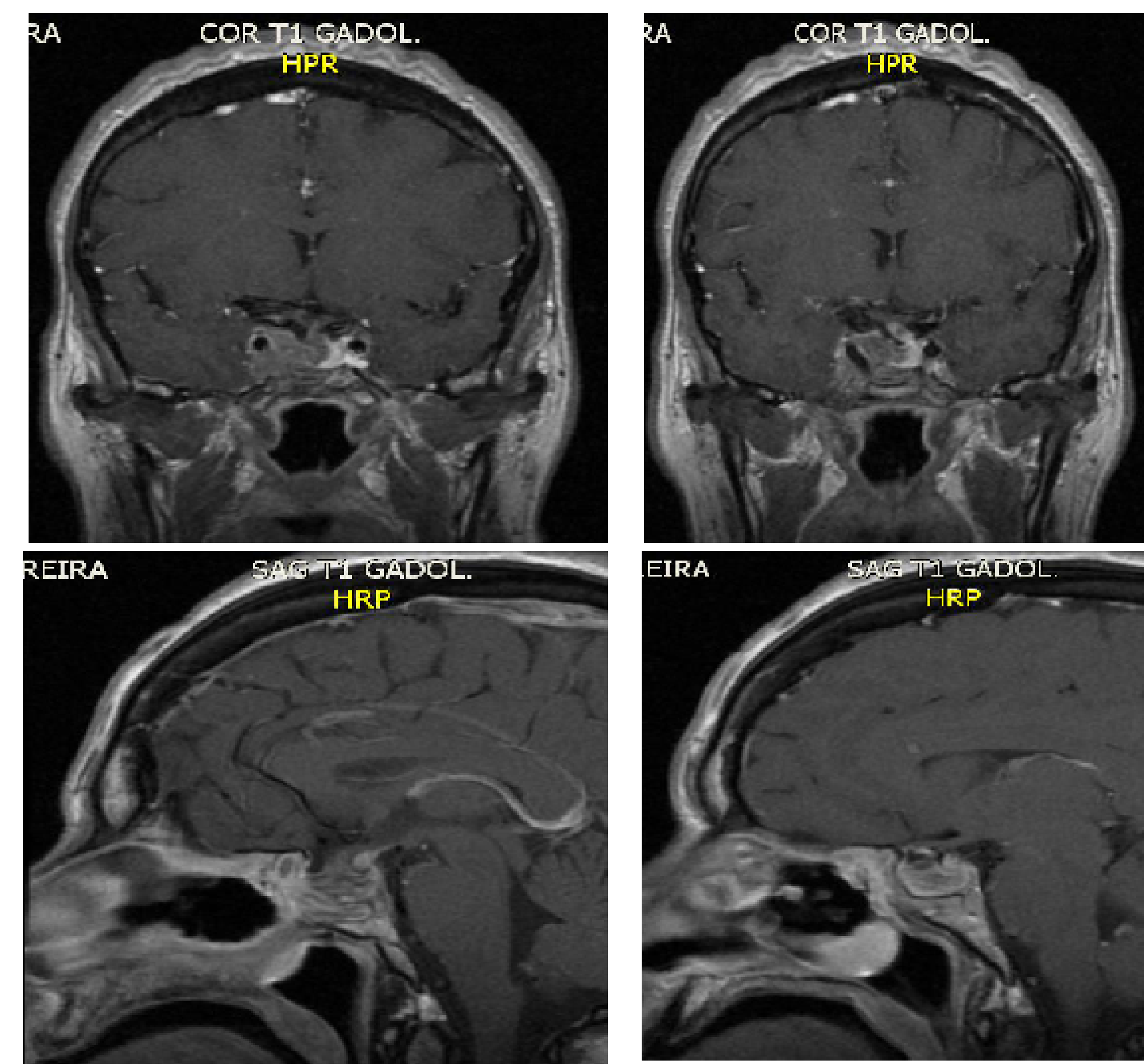

There is no longer compression of the optic chiasm. Persistence of tissue attributable to residual tumor invading the right cavernous sinus.

Fig. 5 - Pituitary MRI november 2014

\begin{tabular}{|l|l|l|l|}
\hline \multicolumn{4}{|c|}{ Table 2. Oral Glucose Tolerance Test - } \\
november 2014 \\
\hline $\begin{array}{l}\text { Tempo } \\
\text { (min) }\end{array}$ & $\begin{array}{l}\text { Glucose } \\
(\mathrm{mg} / \mathrm{dL})\end{array}$ & $\begin{array}{l}\text { Insulin } \\
(\mathrm{uU} / \mathrm{mL})\end{array}$ & $\begin{array}{l}\text { GH } \\
(\mathrm{ng} / \mathrm{mL})\end{array}$ \\
\hline 0 & 86 & 32.8 & 21.8 \\
\hline 30 & 129 & 80.7 & 17.4 \\
\hline 60 & 171 & 75.5 & 13.9 \\
\hline 90 & 154 & 217.5 & 12.8 \\
\hline 120 & 126 & 188.6 & 11.1 \\
\hline
\end{tabular}

She was submitted to transphenoida resection in august 2014

\section{CONCLUSIONS}

This is a case of acromegaly with several predictors of a possible failure of response to somatostatin analogues: young age, elevated levels of GH and IGF-1 at diagnosis, macroadenoma with invasive growth and Ki-67 labeling index of $8 \%$. In the presence of cases of atypical adenomas a multidisciplinary team of endocrinologists, neurosurgeons, pathologists and oncologists must work together in attentive and personalized follow-up of the patient in order to prevent disease progression.

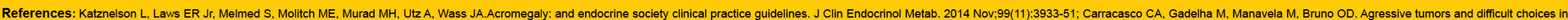

